\title{
BAURAN PEMASARAN DAN PENGARUHNYA TERHADAP MINAT NASABAH UNTUK MENABUNG DI TABUNGAN TAMPAN, BANK SULSELBAR SYARIBULAN *
}

\author{
Fakultas Ekonomi, Universitas Indonesia Timur, Makassar
}

\begin{abstract}
ABSTRAK: Penelitian ini bertujuan untuk menganalisis pengaruh faktor produk tabungan, suku bunga, lokasi, promosi dan pelayanan bank terhadap nasabah dalam memilih TAMPAN pada PT. Bank Sulselbar, Makassar. Data penelitian dikumpulkan menggunakan kuesioner yang dibagikan kepada 100 orang nasabah PT Bank Sulselbar Makassar. Data penelitian yang terkumpul dianalisis menggunakan analisis deskriptif dan analisis regresi berganda. Hasil penelitian ini menunjukan adanya pengaruh dari produk tabungan, suku bunga, lokasi, promosi dan pelayanan Bank berpengaruh terhadap nasabah dalam memilih TAMPAN pada PT. Bank Sulselbar Makassar. Hal ini berarti pihak pemasar, dalam hal ini PT Bank Sulselbar Makassar hendaknya perlu mempertimbangkan kelima hal tersebut dalam memasarkan produk tabungannya.
\end{abstract}

Kata kunci : Produk Tabungan, Suku Bunga, Lokasi, Promosi, Pelayanan Bank, Minat Nasabah

ABSTRACT: This study aimed to analyze factors affecting customers' decision in choosing TAMPAN savings product at PT. Bank Sulselbar, Makassar, e.g. interest rates, location, promotion and bank services to. The research data was collected using questionnaires distributed to 100 customers of PT Bank Sulselbar Makassar. Data collected were then analyzed using descriptive analysis and multiple regression analysis. The results of this study indicated the influence of saving products, interest rates, location, promotion and service affect the customer preference in choosing TAMPAN at PT. Bank Sulselbar Makassar. This means that marketers of PT Bank Sulselbar Makassar should consider these five predictors in their marketing of savings products.

Keywords: saving products, interest rate, location, promotion, bank service, customer interest

* Surel Korespondensi Penulis: syahribulan7@gmail.com 


\section{PENDAHULUAN}

Dalam dunia persaingan perbankan, PT. Bank Sulselbar, Tbk Cabang Utama Makassar pada tanggal 14 Januari 2011 telah meluncurkan produk baru yaitu Tabungan Masa Depan (TAMPAN). Tabungan Masa Depan adalah tabungan berjangka untuk mewujudkan rencana masa depan nasabah seperti: pendidikan anak sekolah, pernikahan, uang muka kendaraan, wisata atau tujuan investasi dalam mata uang Rupiah dengan sistem setoran rutin bulanan yang besarnya disesuaikan dengan kebutuhan dan kemampuan nasabah. Keunggulan dari produk ini, nasabah akan memeroleh asuransi secara gratis yang mencakup setoran nasabah pada saat terjadi kecelakaan atau ketidakmampuan total tetap, bunga relatif tinggi dan pemberian hadiah langsung yang eksklusif untuk setoran tertentu dan bebas biaya administrasi rekening. Sementara untuk tabungan simpeda tidak memiliki waktu jatuh tempo, penarikan dapat dilakukan setiap saat.

Dalam persaingan, pihak Bank cenderung memengaruhi calon nasabah dengan informasi dari faktor-faktor internal berupa sikap inovasi dan keunggulan bersaing melalui perbaikan produk dan sumber daya manusia, sedangkan faktor eksternal yaitu kebudayaan, lingkungan, keuangan, kemajuan teknologi, perubahan sosial, ekonomi, politik dan memertimbangan keuntungan apa saja yang akan diperoleh masyarakat (Efendi, 2018).

Demikian halnya dengan PT. Bank Pembangunan Daerah Sulawesi Selatan dan Sulawesi Barat Cabang Utama Makassar sebagai salah satu perusahaan yang bergerak di bidang jasa perbankan yang dalam melaksanakan kegiatannya diharapkan pada persaingan dengan perusahaan jasa perbankan lainnya (Suhartini \& Anisa, 2017; Parmitasari, 2011). Dalam upaya mengantisipasi perubahan yang terjadi baik internal maupun eksternal, Bank Sulselbar, Tbk Cabang Utama Makassar senantiasa memberikan kontribusi yang optimal terhadap pendapatan melalui layanan unggul dalam penghimpunan dan penyaluran dana pemda dan masyarakat guna meningkatkan pembangunan ekonomi daerah (Parmitasari et al. 2018).

Upaya tersebut antara lain dengan peningkatan nilai manfaat produk yang ditawarkan secara berkelanjutan, meningkatkan kualitas sumber daya yang dimilikinya serta menerapkan strategi pemasaran yang tepat, efektif, dan efisien. Ini dimaksudkan agar Bank Sulselbar,Tbk memiliki daya saing yang kuat untuk pihak yang menempatkan dananya, karena tanpa nasabah maka bank tidak akan memiliki aktivitas apapun (Efendi, 2017).

Salah satu faktor yang berpengaruh dalam menunjang tercapainya tujuan yang dicanangkan oleh manajemen PT Bank Sulselbar, Tbk adalah penerapan dari bauran pemasaran yang berkaitan dengan penentuan bagaimana menyajikan produk pada segmen pasar tertentu yang merupakan pasar sasarannya. Bauran pemasaran merupakan kombinasi variabel atau kegiatan yang merupakan inti dari sistem pemasaran yang dapat dikendalikan dan digunakan oleh manajemen bank untuk memengaruhi reaksi para konsumen dalam hal ini terdiri dari produk tabungan, suku bunga, lokasi dan promosi serta pelayanan Bank yang dapat dijadikan sebagai pedoman bagi pemimpin perusahaan untuk mencapai tujuan perusahaan dalam bidang pemasaran. 
Penelitian ini dimaksudkan untuk mengkaji serta menganalisis seberapa besar faktor-faktor yang memengaruhi minat meliputi produk tabungan, suku bunga, lokasi dan promosi serta pelayanan Bank.

Berdasarkan uraian di atas, masalah pokok penelitian ini dapat dirumuskan sebagai berikut :

1. Apakah faktor produk tabungan, suku bunga, lokasi, promosi dan pelayanan Bank berpengaruh terhadap nasabah dalam memilih tabungan TAMPAN pada PT. Bank Sulselbar, Tbk Cabang Utama Makassar.

2. Di antara produk tabungan, suku bunga, lokasi, promosi dan pelayanan Bank, faktor manakah yang dominan berpengaruh terhadap nasabah dalam memilih Tabungan TAMPAN pada PT. Bank Sulselbar, Tbk Cabang Utama Makassar.

Penelitian ini bertujuan untuk menganalisis pengaruh faktor produk tabungan, suku bunga, lokasi, promosi dan pelayanan Bank terhadap keputusan nasabah untuk menabung pada TAMPAN, serta untuk mengetahui faktor mana yang memberikan pengaruh dominan terhadap keputusan nasabah untuk menabung di TAMPAN.

Secara teoritis, penelitian ini diharapkan dapat mengembangkan ilmu pengetahuan, khususnya Manajemen Pemasaran sebagai literatur pendukung dalam pokok pembahasan faktor-faktor yang memengaruhi konsumen dalam pembelian produk, sehingga dapat dijadikan acuan bagi peneliti lain di waktu yang akan datang. Selain itu penelitian ini juga dapat dijadikan sebagai sumbangan pemikiran untuk dipakai sebagai alternatif dalam strategi pemasaran produk, terutama yang berkaitan dengan faktor-faktor yang memengaruhi keputusan pembelian konsumen.

\section{TINJAUAN TEORITIS}

\section{Bauran Pemasaran Jasa}

Bauran pemasaran termasuk salah satu acuan dalam menyusun strategi pemasaran yang kedudukannya cukup penting, karena keberhasilan perusahaan mencapai tujuan sangat ditentukan oleh sejauh mana bauran pemasaran dilaksanakan. Hal ini sebagai pertimbangan beberapa variabel yang ada dalam bauran pemasaran adalah variabel yang diperhitungkan oleh konsumen dalam menetapkan pembelian suatu produk.

Menurut Kotler (2002), bauran pemasaran (marketing mix) adalah seperangkat variabel pemasaran terkontrol yang dilakukan perusahaan untuk menghasilkan tanggapan yang diinginkan dalam pasar sasaran (target market), terdiri atas produk, tempat, promosi dan harga. Bauran pemasaran merupakan kombinasi variabel-variabel yang digunakan untuk memengaruhi perilaku pembeli pada pasar sasaran. Simanjuntak (2001) memberikan definisi bauran pemasaran dan jasa adalah sekelompok variabel yang dapat dikendalikan dan dipergunakan oleh perusahaan yang bersangkutan untuk memengaruhi reaksi para pembeli, dalam menetapkan keputusan pembelian terhadap suatu produk.

Dari dua pengertian di atas dapat disimpulkan bauran pemasaran merupakan ujung tombak strategi pemasaran yang diimplementasikan pada segmen pasar, target pasar dan posisi pasar, dengan menitikberatkan pada masalah produk, harga, kualitas produk, media promosi dan bentuk saluran 
distribusi serta pelayanan yang diperuntukkan bagi pasar sasaran. Bauran pemasaran harus dilakukan secara efektif dan efisien dengan tujuan agar dapat mempercepat terjadinya penjualan karena variabel tersebut merupakan variabel inti yang dapat dikontrol dan digunakan untuk memengaruhi konsumen dalam menetapkan suatu pembelian terhadap suatu produk dan jasa.

\section{Minat Nasabah}

Minat sebagai aspek kejiwaan bukan hanya mewarnai perilaku seseorang untuk melakukan aktifitas yang menyebabkannya merasa tertarik kepada sesuatu. Minat nasabah menurut Schiffman, Kanuk dan Lazar (2008) yaitu pengaruh eksternal, kesadaran akan kebutuhan, pengenalan produk dan evaluasi alternatif adalah hal yang dapat menimbulkan minat beli konsumen. Pengaruh eksternal terdiri dari usaha pemasaran dan faktor sosial budaya. Dalam kamus Bahasa Indonesia, minat diartikan sebagai niat atau kehendak. Perilaku manusia dipengaruhi oleh kehendak/niat/minat. Minat merupakan keinginan individu untuk melakukan perilaku tertentu sebelum perilaku tersebut dilaksanakan. Adanya niat/minat untuk melakukan suatu tindakan akan menentukan apakah kegiatan tersebut akhirnya akan dilakukan (Fishbein dan Ajzen, 1975). Dengan demikian perilaku merupakan 'niat/minat' yang sudah direalisasikan dalam bentuk tingkah laku yang tampak. Dalam teori Tindakan Beralasan diuraikan bahwa kehendak/minat dipengaruhi oleh sikap dan norma subyektif yang dihubungkan.

Keyakinan terhadap manfaat suatu kegiatan atau hal tertentu akan menimbulkan sikap positip terhadap hal tersebut. Sikap positif akan memengaruhi niat/minat seseorang untuk melakukan kegiatan tersebut. Sikap ini merupakan hasil pertimbangan untung dan rugi dari perilaku tersebut (outcomes of the behavior). Di samping itu juga dipertimbangkan pentingnya konsekuensi yang akan terjadi bagi individu (evaluation regarding the outcome). Komponen berikutnya mencerminkan dampak dari norma-norma subyektif. Norma sosial mengacu pada keyakinan seseorang terhadap bagaimana dan apa yang dipikirkan orang-orang yang dianggapnya penting (referent-person) dan motivasi seseorang untuk mengikuti pikiran tersebut.

Model Theory of Reasoned Action (Fishbein dan Ajzen, 1975) dapat digunakan sebagai alat evaluasi mengenai sikap dan perilaku secara ilmiah, untuk memeroleh konsistensi antara sikap, minat berperilaku dan perilaku yang mengacu pada nilai dan norma-norma dalam kelompok sosial, sebagai indikator penting untuk memprediksikan perilaku yang akan diukur, sehingga pengetahuan awal mengenai aspek sosial dan antropologis merupakan aspek penting, karena cara budaya menghubungkan sikap, minat dan perilaku sangat penting. Seluruh konsepsi ini dibentuk oleh tenaga kerja yang sependapat dengan tujuan perusahaan (Awaluddin, 2016; Nurfarhana \& Said, 2016)

Persepsi yang terbentuk akan menjembatani perilaku jika hal ini menghubungkan pertimbangan sikap dan norma subyektif, serta hubungan komponen ini merupakan penentu penting dari intensi/ niat/minat.

Dari penjelasan di atas, dapat dikembangan hipotesis yang akan diuji sebagai berikut : 
1. Diduga faktor produk tabungan, suku bunga, lokasi, promosi dan pelayanan bank berpengaruh terhadap minat nasabah dalam memilih tabungan TAMPAN pada PT. Bank Sulselbar, Tbk Cabang Utama Makassar.

2. Di antara kelima faktor tersebut, produk tabungan memberikan pengaruh dominan terhadap nasabah dalam memilih tabungan TAMPAN pada PT. Bank Sulselbar, Tbk Cabang Utama Makassar.

\section{METODE PENELITIAN}

Penelitian ini merupakan penelitian eksplanasi, yang menggunakan teknik survei dalam pengumpulan data. Adapun lokasi atau obyek penelitian yaitu pada PT Bank SulselBar, Tbk. Cabang Utama Makassar. Penelitian ini dilakukan selama kurang lebih 3 bulan, terhitung mulai bulan Agustus sampai dengan Oktober 2017.

Metode pengumpulan data yang digunakan adalah penelitian langsung (Field research) yaitu penelitian dilakukan dengan cara observasi langsung dan wawancara dengan nasabah yang menjadi responden. Selanjutnya penelitian kepustakaan (library research) yaitu penelitian yang dilaksanakan dengan memelajari berbagai literatur, buku, referensi, dokumen, dan sebagainya yang berkaitan dengan objek pembahsan sebagai bahan analisis.

Populasi dalam penelitian ini adalah semua nasabah PT Bank SulSelBar, Tbk. Cabang Utama Makassar yang menabung pada TAMPAN, sebanyak 10.437 orang. Penentuan jumlah sampel dalam penelitian ini menggunakan pendekatan rumus dari Taro Yamane (Riduwan, 2008), dengan formula sebagai berikut :

di mana :

$$
n=\frac{N}{1+N \cdot d^{2}}
$$

$\mathrm{n}=$ Jumlah sampel

$\mathrm{d}=$ Faktor kesalahan $(10 \%)$

$\mathrm{N}=$ Jumlah populasi

Dari jumlah populasi 10.437 orang dan faktor kesalahan yang diambil 0,10, jumlah sampel yang diambil adalah :

$$
\begin{gathered}
n=\frac{N}{1+N \cdot d^{2}} \\
n=\frac{10.437}{1+10.437\left(0,10^{2}\right)} \\
n=\frac{10.437}{105,37} \\
\mathrm{n}=99.05, \text { dibulatkan } 100
\end{gathered}
$$

Teknik pengambil sampel yang digunakan adalah teknik accidental sampling, yaitu teknik penarikan sampel secara kebetulan yaitu nasabah yang mau menabung dan atau menyetor tabungannya pada saat pengumpulan data dilakukan.

Kuesioner yang digunakan dalam penelitian ini disusun mengacu pada Skala Likert yang merupakan salah satu bentuk dari Skala Sikap dengan skor 1 (sangat Tidak steuju) - 5 (Sangat Setuju). 
Metode analisis yang digunakan adalah analisis deskriptif dalam bentuk tabulasi frekuensi dan analisis regresi berganda. Analisis deskriptif untuk menafsirkan data dan keterangan yang diperoleh dengan jalan mengumpulkan, menyusun dan mengklasifikasikan data yang diperoleh yang selanjutnya akan digunakan untuk memberikan gambaran sebenarnya mengenai faktor-faktor yang memengaruhi minat nasabah untuk menabung di TAMPAN. Sedangkan analisis regresi linear berganda (multiple linear regression), digunakan untuk mengetahui pengaruh antara variabel bebas (produk tabungan, suku bunga, lokasi, promosi dan pelayanan Bank) terhadap variabel terikat (minat nasabah dalam memilih tabungan TAMPAN). Persamaan regresi linear berganda dengan lima variabel bebas yaitu :

di mana:

$$
Y=b_{0}+b_{1} X_{1}+b_{2} X_{2}+b_{3} X_{3}+b_{4} X_{4}+b_{5} X_{5}+\varepsilon
$$

$\begin{array}{ll}\mathrm{b}_{0} & =\text { Konstanta } \\ \mathrm{b}_{1}, \mathrm{~b}_{2}, \mathrm{~b}_{3}, \mathrm{~b}_{4}, \mathrm{~b}_{5} & =\text { Koefisien regresi } \\ \mathrm{Y} & =\text { Minat nasabah } \\ \mathrm{X}_{1} & =\text { Produk tabungan } \\ \mathrm{X}_{2} & =\text { Suku bunga } \\ \mathrm{X}_{3} & =\text { Lokasi bank } \\ \mathrm{X}_{4} & =\text { Promosi } \\ \mathrm{X}_{5} & =\text { Pelayanan bank } \\ \varepsilon & =\text { Standard Error }\end{array}$

Pengujian hipotesis dilakukan dengan cara uji t untuk melihat secara parsial apakah ada pengaruh yang signifikan dari variabel bebas produk tabungan, suku bunga, lokasi, promosi dan pelayanan bank terhadap minat nasabah sebagai variabel terikat. Koefisien Determinan $\left(R^{2}\right)$ digunakan untuk melihat seberapa besar pengaruh variabel bebas terhadap variabel terikat. Dengan kata lain koefisien determinan digunakan untuk mengukur besarnya pengaruh variabel bebas yaitu produk tabungan, suku bunga, lokasi, promosi dan pelayanan bank terhadap minat nasabah yang merupakan variabel terikat.

\section{PEMBAHASAN}

Karakteristik Responden

Responden penelitian ini berjumlah 100 orang nasabah yang menabung di TAMPAN PT Bank Sulselbar Tbk, Cabang Utama Makassar. Hasil tabulasi menunjukan bahwa mereka terdiri dari 61 orang $(61 \%)$ laki-laki dan 39 orang $(39 \%)$ perempuan. Menurut kelompok umur, responden yang berusia di bawah 30 tahun sebanyak 17 orang (17\%), antara 31-50 tahun sebanyak 60 orang $(60 \%)$, dan selebihnya berusia 51 tahun ke atas sebanyak 23 orang (23\%). Selanjutnya responden penelitian ini yang memiliki tingkat pendidikan SMA/Sederajat sebanyak 16 orang $(16 \%)$, diploma sebanyak 36 orang $(36 \%)$, sarjana sebanyak 40 orang $(40 \%)$, dan pascasarjana sebanyak 8 orang $(8 \%)$. Menurut jenis pekerjaan, responden yang bekerja sebagai pegawai negeri sipil sebanyak 18 orang $(18 \%)$, pegawai swasta sebanyak 27 orang $(27 \%)$, wirausahawan sebanyak 4 orang $(4 \%)$, anggota TBI/Polri sebanyak 1 orang $1 \%)$, professional 
sebanyak 12 orang (12\%), serta jenis pekerjaan lainnya sebanyak 20 orang $(20 \%)$. Sementara itu, responden yang memiliki penghasilan per bulan kurang dari Rp. 5.000.000,- sebanyak 2 orang (2\%), penghasilan antara Rp 5.000.000,sampai dengan Rp 10.000.000,- sebanyak 47 orang $(47 \%)$, dan lebih dari Rp. 10.000.000,- sebanyak 51 orang (51\%). Sedangkan amanya mereka menjadi nasabah $<1$ tahun sebanyak 22 orang (22\%), antara 1-3 tahun sebanyak 53 orang $(53 \%)$, serta lebih dari 5 tahun sebanyak 25 orang $(25 \%)$.

\section{Deskripsi Variabel Penelitian}

Hasil deskripsi variabel produk tabungan menunjukan rata-rata responden memiliki persepsi yang sangat baik terhadap produk tabungan masa depan (TAMPAN) yang ditawarkan oleh PT Bank Sulselbar Tbk. Cabang Utama Makassar. Hal ini merupakan indikasi produk yang ditawarkan oleh pihak bank memiliki keunggulan dan keunikan dibandingkan dengan produk tabungan sejenis yang ditawarkan oleh bank pesaing. TAMPAN merupakan tabungan berjangka (Installment Saving) yang dapat membantu nasabah dalam mewujudkan rencana masa depan, seperti pendidikan anak, pernikahan, uang muka kendaraan, wisata atau tujuan investasi. TAMPAN diselenggarakan dalam mata uang rupiah dengan sistem setoran rutin bulanan yang besarnya disesuaikan dengan kebutuhan dan kemampuan penabung. Sebagai tabungan berjangka TAMPAN memiliki jangka waktu 2 - 5 tahun dengan pilihan setoran minimum secara rutin Rp.100.000,- per bulan. Keunggulan dari produk ini adalah nasabah akan memperoleh asuransi secara gratis yang akan mengcover setoran nasabah pada saat terjadi kecelakaan, bunga yang relatif tinggi dan pemberian hadiah langsung saat membuka tabungan, serta bebas biaya administrasi rekening. Salah satu ketentuan yang harus dipenuhi nasabah TAMPAn adalah kepemilikan rekening Simpeda dan atau Tapemda pada bank Sulselbar Tk. Yang berfungsi sebagai rekening sumber. Selanjutnya hasil analisis deskriptif juga menunjukan rata-rata responden memiliki persepsi yang baik terhadap tingkat suku bunga yang ditawarkan oleh PT Bank Sulselbar Tbk. Cabang Utama Makassar atas simpanan nasabah di TAMPAN. Hal ini mengingat tingkat suku bunga yang diberikan atas TAMPAN lebih tinggi di atas suku bunga simpanan tabungan lainnya, baik yang diselenggaraakn oleh PT Bank Sulselbar Tbk. Maupun oleh bank pesaingnya. Kemudian hasil analisis deskriptif atas variabel lokasi bank juga menunjukan persepsi nasabah atas lokasi bank cukup baik. Hal ini dimungkina karena lokasi kantor bank mudah dijangkau oleh setiap nasabah. Hasil analisis deskriptif atas variabel promosi juga menunjukan rata-rata responden memiliki persepsi yang baik. Seb agai produk baru yang masih berada pada tahap akhir masa perkenalannya di pasar, pihak PT Bank Sulselbar Tbk. Selalau berusaha menyelenggarakan program promosi untuk menarik perhatian nasabah baru, antara lain dengan menginformasikan kehadiran produk TAMPAN bagi nasabah yang membuka rekening Simpeda dan atau Tapemda di semua kantor cabang dan unitnya. Dengan promosi seperti ini, terjadi peningkatan jumlah nasabah yang cukup signifikan sejak kehadiran TAMPAN hingga saat 
ini. Hasil deskripsi variabel layanan bank menunjukan rata-rata responden memiliki persepsi yang baik pula atas pelayanan yang diebrikan oleh pihak bank, baik pada saat membuka rekening TAMPAn maupun saat transaksi penyetoran berjalan. Hasil analisis deskriptif menunjukan adanya persepsi responden yang baik atas variabel minat nasabah untuk menabung di TAMPAN PT Bank Sulselbar, Tbk Cabang Utama Makassar. Hasil ini dimungkinkan karena responden telah menjadi nasabag PT Bank Sulselbar Tbk. Sebelumnya sehingga ketika mendapatkan informasi tentang TAMPAN, secara cepat membangkitkan minatnya untuk menabung pula di TAMPAN.

\section{Hasil Penelitian} berikut.

Hasil perhitungan menggunakan SPSS 21 menunjukan hasil sebagai

Tabel 1. Coefficients

\begin{tabular}{lrrrrr}
\hline \multicolumn{7}{c}{$\begin{array}{c}\text { Unstandardized } \\
\text { Coefficients }\end{array}$} & \multicolumn{2}{c}{$\begin{array}{c}\text { Standardized } \\
\text { Coefficients } \\
\text { Model }\end{array}$} & \multicolumn{1}{c}{ B } & Std. Error & \multicolumn{1}{c}{ Beta } & \multicolumn{1}{c}{ t } & \multicolumn{1}{c}{ Sig. } \\
\hline 1 (Constant) &, 574 &, 167 & & 3,443 &, 003 \\
$\quad$ Produk Tabungan &, 737 &, 087 &, 722 & 8,434 &, 000 \\
$\quad$ Suku Bunga &, 883 &, 193 &, 125 & 4,564 &, 005 \\
$\quad$ Lokasi Bank &, 434 &, 094 &, 550 & 4,613 &, 006 \\
$\quad$ Promosi &, 765 &, 193 &, 654 & 3,963 &, 004 \\
$\quad$ Layanan Bank & 1,000 &, 131 & 1,072 & 7,641 &, 000 \\
\hline
\end{tabular}

a. Dependent Variable: Minat Nasabah

Sumber : Hasil perhitungan, 2017

Berdasarkan hasil pengelolahan data seperti yang terlihat pada tabel di atas, diperoleh persamaan regresi sebagai berikut :

$$
Y=0,574+0,737 X 1+0,883 X_{2}+0,434 X_{3}+0,784 X_{4}+1,000 X_{5}+0,144
$$

Dari persamaan tersebut dapat diuraikan sebagai berikut:

Konstanta $\left(b_{0}\right)$ bernilai 0,574 menunjukkan jika tidak ada pengaruh faktor produk tabungan, suku bunga, lokasi bank, promosi, dan layanan bank, minat nasabah untuk menabung di TAMPAN PT Bank Sulselbar, Tbk Cabang Utama Makassar akan tetap ada sebesar 0,574.

Koefisien regresi $b_{1}$ sebesar 0,737 menunjukkan faktor produk tabungan berpengaruh positif terhadap minat nasabah untuk menabung di TAMPAN PT Bank Sulselbar, Tbk Cabang Utama Makassar. Artinya setiap terjadi peningkatan persepsi nasabah terhadap faktor produk tabungan sebesar satu satuan maka minat nasabah untuk menabung di TAMPAN PT Bank Sulselbar, Tbk Cabang Utama Makassar juga akan meningkat sebesar 0,737.

Koefisien regresi $b_{2}$ sebesar 0,883 menunjukkan faktor suku bunga berpengaruh positif terhadap minat nasabah untuk menabung di TAMPAN PT Bank Sulselbar, Tbk Cabang Utama Makassar. Artinya setiap terjadi peningkatan persepsi nasabah terhadap faktor suku bunga sebesar satu satuan maka minat nasabah untuk menabung di TAMPAN PT Bank Sulselbar, Tbk Cabang Utama Makassar juga akan meningkat sebesar 0,883. 
Koefisien regresi $b_{3}$ sebesar 0,434 menunjukkan faktor lokasi bank berpengaruh positif terhadap minat nasabah untuk menabung di TAMPAN PT Bank Sulselbar, Tbk Cabang Utama Makassar. Artinya setiap terjadi peningkatan persepsi nasabah terhadap faktor lokasi bank sebesar satu satuan maka minat nasabah untuk menabung di TAMPAN PT Bank Sulselbar, Tbk Cabang Utama Makassar juga akan meningkat sebesar 0,737.

Koefisien regresi $b_{4}$ sebesar 0,765 menunjukkan faktor promosi berpengaruh positif terhadap minat nasabah untuk menabung di TAMPAN PT Bank Sulselbar, Tbk Cabang Utama Makassar. Artinya setiap terjadi peningkatan persepsi nasabah terhadap faktor promosi sebesar satu satuan maka minat nasabah untuk menabung di TAMPAN PT Bank Sulselbar, Tbk Cabang Utama Makassar juga akan meningkat sebesar 0,765.

Koefisien regresi $b_{5}$ sebesar 1,000 menunjukkan faktor layanan bank berpengaruh positif terhadap minat nasabah untuk menabung di TAMPAN PT Bank Sulselbar, Tbk Cabang Utama Makassar. Artinya setiap terjadi peningkatan persepsi nasabah terhadap faktor layanan bank sebesar satu satuan maka minat nasabah untuk menabung di TAMPAN PT Bank Sulselbar, Tbk Cabang Utama Makassar juga akan meningkat sebesar 1,000.

Jadi dapat disimpulkan faktor layanan bank sangat berperan untuk membuat nasabah berminat menabung di TAMPAN PT Bank Sulselbar, Tbk Cabang Utama Makassar, sehingga semakin tinggi persepsi nasabah atas layanan yang diberikan oleh pihak bank maka semakin meningkat pula minat mereka untuk menabung di TAMPAN PT Bank Sulselbar, Tbk Cabang Utama Makassar.

Nilai $t_{\text {tabel }}$ diketahui sebesar 2,63, sehingga dengan memerhatikan tabel 1 di atas nilai thitung variabel produk tabungan 8,434 berarti $t_{\text {hitung }}>t_{\text {tabel }}$ dengan nilai signifikansi 0,000 sehingga dapat disimpulkan variabel produk tabungan secara parsial berpengaruh positif dan signifikan terhadap minat nasabah untuk menabung di TAMPAN PT Bank Sulselbar, Tbk. Cabang Utama

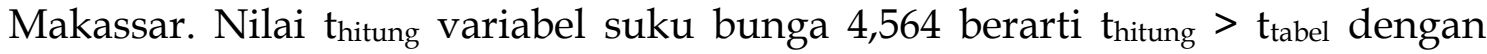
nilai signifikansi 0,005 sehingga dapat disimpulkan variabel suku bunga secara parsial berpengaruh positif dan signifikan terhadap minat nasabah untuk menabung di TAMPAN PT Bank Sulselbar, Tbk. Cabang Utama Makassar. Nilai thitung variabel lokasi bank 4,613 berarti $t_{\text {hitung }}>t_{\text {tabel }}$ dengan nilai signifikansi 0,006 sehingga dapat disimpulkan variabel lokasi bank secara parsial berpengaruh positif dan signifikan terhadap minat nasabah untuk menabung di TAMPAN PT Bank Sulselbar, Tbk. Cabang Utama Makassar. Nilai thitung variabel promosi 3,963 berarti $t_{\text {hitung }}>t_{\text {tabel }}$ dengan nilai signifikansi 0,004 sehingga dapat disimpulkan variabel promosi secara parsial berpengaruh positif dan signifikan terhadap minat nasabah untuk menabung di TAMPAN PT Bank Sulselbar, Tbk. Cabang Utama Makassar. Nilai thitung variabel layanan bank 7,641 berarti thitung $>t_{\text {tabel }}$ dengan nilai signifikansi 0,000 sehingga dapat disimpulkan variabel layanan bank secara parsial berpengaruh positif dan signifikan terhadap minat nasabah untuk menabung di TAMPAN PT Bank Sulselbar, Tbk. Cabang Utama Makassar.

Koefisien determinasi $\left(\mathrm{R}^{2}\right)$ digunakan untuk mengukur besarnya 
persentase kemampuan variabel bebas produk tabungan, suku bunga, lokasi bank, promosi, dan layanan bank dalam memengaruhi minat nasabah untuk menabung di TAMPAN PT Bank Sulselbar, Tbk Cabang Utama Makassar. Hasil pengujiannya disajikan dalam tabel 2 berikut.

Tabel 2. Model Summary

\begin{tabular}{|c|c|c|c|c|}
\hline Model & $\mathrm{R}$ & R Square & Adjusted R Square & Std. Error of the Estimate \\
\hline 1 & $925^{a}$ & ,856 & 849 & 26314 \\
\hline
\end{tabular}

Sumber : Hasil perhitungan, 2017

Berdasarkan tabel di atas diketahui koefisien korelasi yang menunjukkan hubungan antara minat nasabah untuk menabung di TAMPAN PT Bank Sulselbar Tbk. Cabang Utama Makassar dengan faktorfaktor yang memengaruhinya adalah cukup kuat, yang ditunjukan dengan nilai $\mathrm{R}=0,925$. Kemampuan model tersebut untuk menjelaskan setiap perubahan variabel terikat $(\mathrm{Y})$ dapat dilihat pada kolom Adjusted $R$ square yaitu sebesar 0,849 atau $84,9 \%$. Hal ini menunjukkan bahwa variasi naik turunnya minat nasabah untuk menabung di TAMPAN PT Bank Sulselbar Tbk Cabang Utama Makassar dipengaruhi oleh faktor produk tabungan, suku bunga, lokasi bank, promosi, dan layanan bank. Nilai koefisien determinan (R2) sebesar 0,856 menunjukan besarnya pengaruh faktor produk tabungan, suku bunga, lokasi bank, promosi, dan layanan bank secara bersama-sama terhadap minat nasabah untuk menabung di TAMPAN PT Bank Sulselbar, Tbk Cabang Utama Makassar. Sementara nilai standar eror estimasi 0,26314 menunjukan kemampuan model penelitian ini untuk menjelaskan keadaan yang sebenarnya, di mana semakin kecil nilainya berarti semakin baik model ini digunakan sebagai alat prediksi.

\section{Pembahasan}

Hasil penelitian ini menunjukan adanya pengaruh yang positif dari semua variabel bebas yang diteliti terhadap variabel terikat. Artinya minat nasabah untuk menabung di TAMPAN PT Bank Sulselbar dipengaruhi oleh faktor produk, suku bunga, lokasi bank, promosi, dan pelayanan bank. Di antara faktor-faktor tersebut, pelayanan bank merupakan faktor yang memberi pengaruh lebih dominan terhadap pembentukan minat nasabah untuk menabung di TAMPAN. Temuan ini dimungkinkan karena pada hakekatnya kepuasan konsumen sangat dipengaruhi oleh pelayanan yang di terima dari pemberi jasa. Sebagus apapun produk yang ditawarkan dan promosi yang dilakukan, akan tidak berarti apa-apa bagi konsumen ketika pelayanan yang didapatkan tidak seperti yang diharapkan. Hal ini tidak terlepas dari karakteristik jasa yang tidak berwujud, tidak bisa dimiliki, serta produksi dan konsumsinya terjadi pada saat bersamaan. Selain itu, pemberian pelayanan sebenarnya merupakan upaya untuk memenuhi janji yang diberikan oleh pemasar dalam kegiatan promosi. Pelayanan yang berkualitas akan membuktikan pemasar tidak over promise and under deliver. Pelayanan yang sesuai dengan harapan nasabah akan memberikan kepuasan bagi mereka, dan 
sebaliknya jika kurang dari yang diharapkan, akan menimbulkan ketidakpuasan.

Hasil penelitian ini sejalan dengan beberapa penelitian sebelumnya yang menemukan pengaruh dari produk (Basuki, dkk., 2008; Yupitri dan Sari, 2012; Tambunan dan Nasution, 2013; Arifin dan Khotimah, 2014; Djunaedi, 2016; Murti dan Santika, 2016; Pary, 2017), suku bunga (Tambunan dan Nasution, 2013;), lokasi bank (Tambunan dan Nasution, 2013; Arifin dan Khotimah, 2014; Fahrudin, dan Yulianti, 2015; Murti dan Santika, 2016;), promosi (Tambunan dan Nasution, 2013; Arifin dan Khotimah, 2014; Fahrudin, dan Yulianti, 2015; Sarwita, 2017;), dan kualitas layanan (Churchil and Suprenant, 1982; Singh and Kaur, 2011; Barat and Spillan, 2012; Marbun dan Mardhono, 2012; Tambunan dan Nasution, 2013; Arifin dan Khotimah, 2014; Fahrudin, dan Yulianti, 2015; Saleky, et. al, 2014a, 2014b, 2015, 2016; Salhuteru, 2017, Pary, 2017; Sarwita, 2017; Wahdi, Wardana, dan Suprapti, 2017).

\section{PENUTUP}

Kesimpulan

Penelitian ini bertujuan untuk menganalisis pengaruh faktor produk tabungan, suku bunga, lokasi bank, promosi, dan layanan bank terhadap minat nasabah untuk menabung di TAMPAN PT Bank Sulselbar, Tbk Cabang Utama Makassar. Dari pembahasan di atas, kesimpulan yang dapat diambil antara lain :

1. Faktor produk tabungan, suku bunga, lokasi, promosi dan pelayanan bank berpengaruh terhadap minat nasabah dalam memilih tabungan TAMPAN pada PT. Bank Sulselbar, Tbk Cabang Utama Makassar.

2. Di antara kelima faktor tersebut, produk tabungan memberikan pengaruh dominan terhadap nasabah dalam memilih tabungan TAMPAN pada PT. Bank Sulselbar, Tbk Cabang Utama Makassar.

Saran

Dari hasil penelitian ini, saran yang dapat dikemukakan bagi pihak PT Bank Sulselbar Tbk. Cabang Utama Makassar untuk senantiasa berupaya meningkatkan kualitas pelayanan yang diberikan kepada nasabah dan calon nasabah, karena kualitas pelayanan merupakan pemenuhan janji yang telah diberikan kepada pasar saaran melalui aktivitas promosi.

\section{DAFTAR PUSTAKA}

Arifin, Atwal dan Husnul Khotimah. 2014. Pengaruh Produk, Pelayanan, Promosi dan Lokasi Terhadap Keputusan Masyarakat Memilih Bank Syariah di Surakarta, Prosiding Seminar Nasional dan Call For Paper Program Studi Akuntansi-FEB UMS, 25 Juni, 165-184

Arma, Ahmad Rijal, \& Syariati, Alim. (2015). Determinan Perilaku Kewargaan Organisasi di Pemerintah Kota PALU.Jurnal Manajemen Ide dan Inspirasi, 2(2), 24-49. 
Awaluddin, Murtiadi. (2016). Pengaruh Budaya Organisasi, Kepuasan dan Lingkungan Kerja Terhadap Kinerja Dosen UIN Alauddin Makassar. In Assets (Vol. 6, No. 1, pp. 116-125).

Barat, Somjit and Spillan, John E. 2012. An Exploratory Study of Customer Satisfaction in a Community Bank, International Journal of Customer Relationship Marketing and Management, Vol. 3, No. 3, July-September, 1532

Basuki, Agus, Ma'mun Sarma dan Budi Purwanto. 2008. Faktor-Faktor yang Mempengaruhi Keputusan Pengusaha Kecil Menengah untuk Menabung (Studi Kasus : BNI Cabang Cianjur, Jawa Barat), Jurnal MPI, Vol. 3 No. 2. September, 54-63

Churchill, Gilbert A. Jr. 1982. An Investigation into the Determinants of Customer Satisfaction, Journal of Marketing Research, Vol. 19, No. 4, Nov, 491-504

Djunaedi, 2016. Pengaruh Corporate Social Responsibility (CSR), dan Kualitas Produk Terhadap, Citra Bank dan Keputusan Menabung di BNI Syariah Kota Kediri, JMM Jurnal Ilmu Ekonomi \& Manajemen, September, Vol. 3, No.2, $104-119$

Efendi, Ahmad. (2017). Pengaruh Atribut Produk dan Perilaku Pencarian Variasi terhadap Perilaku Mahasiswa Berpindah Merek Ponsel pada Fakultas Ekonomi dan Bisnis Islam UINAM. Jurnal Manajemen Ide dan Inspirasi, 4(2), 63-75.

Efendi, Ahmad. (2018). Analisis Positioning Industri Perbankan Syariah di Indonesia. Al-Mashrafiyah (Jurnal Ekonomi, Keuangan dan Perbankan Syariah), 1(1).

Fahrudin, Muhammad Fajar dan Emma Yulianti. 2015. Pengaruh Promosi, Lokasi, dan Kualitas Layanan Terhadap Keputusan Pembelian Nasabah Bank Mandiri Surabaya, Journal of Business and Banking, Volume 5 Number 1, May - October, 149 - 162

Fishbein, M. and Ajzen. 1975. Belief, Attitude, Intention and Behavior, An Introduction to Theory and Research, London : Addison-Wesley Publishing Corp.

Kondoy, Beatric M . J., Bernhard Tewal, dan Frederik Worang. 2016. Bauran Pemasaran dan Pengaruhnya Terhadap Keputusan Menjadi Nasabah Di BPR Prisma Dana Manado, Jurnal EMBA, Vol. 4, No.4 Desember, 1025 1036

Kotler, Philip, 2002, Manajemen Pemasaran 1,Edisi Milenium, Prenhallindo, Jakarta.

Marbun, Dony S. dan Mardhono. 2012. Analisis Persepsi dan Aspirasi Nasabah Terhadap Kualitas Pelayanan BritAma (Studi Kasus Nasabah BritAma PT Bank Rakyat Indonesia (Persero) Tbk. Cabang Martadinata Malang), JESP, Vol. 4, No. 1, 73-92

Murti, I Putu Wira dan I Wayan Santika. 2016. Pengaruh Kepercayaan Nasabah, Bauran Produk dan Bauran Lokasi Terhadap Transaksi Nasabah, E-Jurnal Manajemen Unud, Vol. 5, No.1, 734-761 
Nurfarhana, S., \& Said, Salmah. (2017). Pendekatan Syariah dalam Pemberian Gaji dan Bonus Pengaruhnya terhadap Motivasi Kerja Pegawai. AlMashrafiyah (Jurnal Ekonomi, Keuangan dan Perbankan Syariah), 1(1).

Parmitasari, Rika Dwi Ayu, Djabir Hamzah, Syamsu Alam, \& Abdul Rakhman Laba. (2018). Analysis of Ethics and Investor Behavior and Its Impact on Financial Satisfaction of Capital Market Investors. Scienctific Research Journal (SCIRJ), Vol. 4, Issue I, 2018

Parmitasari, Rika Dwi Ayu., 2011. Struktur Organisasi Dan Kepuasan Kerja Karyawan. Samata: Alauddin University Press

Pary, Gilman. 2017. Faktor yang Memengaruhi Kepuasan Nasabah Bank Muamalat Cabang Ambon. Jurnal Manajemen Ide dan Inspirasi, Vol.4. No. 2, Desember, 49-62

Said, Salmah., \& Amiruddin, A. M. A. (2016). Social Entrepreneurship: Initiative Efforts from Higher Education Classrooms.

Saleky, Saul Ronald Jacob, Dian Utami Sutiksno, Aldina Shiratina, 2014, The Effect of Service Quality on Customer Satisfaction of The Manise Hotel in Ambon, Indonesia, Proceeding of $2^{\text {nd }}$ GARCOMBS

Saleky, Saul Ronald Jacob, Wendy Souisa, Wylda Olivia Kowey, dan Herlina Syarifuddin. 2016. The Association of Service Quality, Price of Service and Brand Equity on Customer Satisfaction and Retention of Star-Hotel Guests in Ambon, Maluku Province, in Bendesa, I.K. G., Meydianawathi, L.G., Handra, Hefrizal., Hartono, Djoni., Priyarsono, D.S., Resosudarmo, Budi P., and Yusuf, Arif A., 2016. Tourism and Sustainable Development in Indonesia, IRSA Serial Book No. 14

Saleky, Saul Ronald Jacob, Wendy Souisa, Wylda Olivia Kowey, Herlina Syarifuddin. 2015. Contribution of Service Quality, Price of Service and Brand Equity on Customer Satisfaction and Retention of Star Hotel Users in Ambon Town, Proceeding 5th IRSA Institute Conference

Salhuteru , Andrie Ch. 2017. Pengaruh Kualitas Layanan Dan Kepuasan Pasien Terhadap Words of Mouth Pada Rumah Sakit Umum Daerah Dr. M. Haulussy Ambon, Jurnal Manajemen Ide dan Inspirasi, Vo. 4, No. 1, Juni, 8494

Sarwita, H. Ade. 2017. Pengaruh Kualitas Pelayanan dan Promosi Terhadap Keputusan Nasabah untuk Menabung (Studi Kasus Pada Perumda BPR Majalengka), MAKSI Jurnal Ilmiah Manajemen \& Akuntansi, Vol. 4, Nomor 1, Periode Januari - Juni, 36-45

Schiffman, Leon. Kanuk, Leslie Lazar. 2008. Perilaku Konsumen. Edisi ketujuh. Jakarta: Index Puri Media Kembangan.

Simanjuntak, Payaman, J., 2001. Manajemen Pemasaran, Edisi Pertama, Cetakan Kedua, Jakarta : Pustaka Binaan Pressindo

Singh, Jaspal and Kaur, Gagandeep. 2011. Customer Satisfaction and Universal Banks : An Empirical Study, International Journal of Customer and Management, Vol. 21, No. 4, 327-348

Suhartini, Eka., \& Anisa, N. (2017). Pengaruh Kecerdasan Emosional Dan Kecerdasan Spiritual Terhadap Kinerja Perawat Rumah Sakit Daerah Labuang Baji Makassar. Jurnal Manajemen Ide dan Inspirasi, 4(01). 
Syariati, Alim \& Namla Elfa Syariati. 2012. Islamic Bank as Bank of Ethics. In Proceeding of Annual South East Asian International Seminar.

Tambunan, Monang Ranto dan Inggrita Gusti Sari Nasution.20.13. Analisis Faktor-Faktor yang Mempengaruhi Keputusan Nasabah Menabung di Bank BCA Kota Medan (Studi Kasus Etnis Cina), Jurnal Ekonomi dan Keuangan, Vol. 1, No. 3, Februari, 193-204

Wadhi, Yohanes Paulus Hanny, Made Wardana, Ni Wayan Sri Suprapti. 2017. Pengaruh Kualitas Layanan Terhadap Tingkat Kepuasan dan Word Of Mouth Pelanggan Micedi Ramada Bintang Bali Resort, E-Jurnal Ekonomi dan Bisnis Universitas Udayana, 6.6 : 2361-2386

Yupitri, Evi dan Raina Linda Sari. 2012. Analisis Faktor-Faktor yang Memengaruhi Non Muslim Menjadi Nasabah Bank Syariah Mandiri di Medan, Jurnal Ekonomi dan Keuangan, Vol. 1, No. 1, Desember, 46-60 